Silviu N. Bunta

Milwaukee, Wisconsin, USA

\title{
THE MĒSU-TREE AND THE ANIMAL INSIDE: THEOMORPHISM AND THERIOMORPHISM IN DANIEL 4
}

The fourth chapter of the Book of Daniel has received extensive attention from recent scholarship. ${ }^{1}$ While modern scholarship has long noted the literary connections of Daniel 4 with Ezekiel 31, it has consistently disregarded the theomorphic character of the enormous tree in Ezekiel 31 and the ideological connections of Daniel 4 with the exilic and post-exilic theomorphic anthropology that underlies Ezekiel 31. It has established no associations between Daniel 4 and the exilic and post-exilic interests in Adam's physical resemblance to YHWH and the concurrent concerns with legitimate expressions of iconic venerations.

An analysis of Daniel 4 within its context and against the background of earlier biblical and ancient Near Eastern sources will evince the focus of the story on the issue of legitimate channels of iconic worship and the theomor-

${ }^{1}$ E.g., M. Henze, Nebuchadnezzar's Madness (Daniel 4) in Syriac Literature // The Book of Daniel: Composition and Reception / Ed. J. J. Collins, P. W. Flint. 2 vols. (Leiden-Boston-Koln, 2001) Vol. 2. 550-571; IDEM, Madness of King Nebuchadnezzar: The Ancient Near Eastern Origins and Early History of Interpretation of Daniel 4 (Leiden, 1999) (JSJSup, 61); S. M. PAUL, The Mesopotamian Babylonian background of Daniel 1-6// The Book of Daniel: Composition and Reception... Vol. 1. 55-68; T. Meadowcroft, Point of View in Storytelling: An Experiment in Narrative Criticism in Daniel 4 // Didaskalia 8 (1997) 30-42; P. Grelot, Nabuchodonosor changé en bête // VT 44 (1994) 10-17; H. F. RichTER, Daniel 4, 7-14: Beobachtungen und Erwagungen // The Book of Daniel in the Light of New Findings (Louvain, 1993) 244-248; K. Koch, Gottes Herrschaft über das Reich des Menschen: Daniel 4 im Licht neuer Funde // The Book of Daniel in the Light of New Findings... 77-119; P. W. Coxon, Another Look at Nebuchadnezzar's Madness // The Book of Daniel in the Light of New Findings... 211-222; IDEM, The Great Tree of Daniel // A Word in Season: Essays in Honour of William McKane / Ed. J. D. Martin, Ph. R. Davies (Sheffield, 1986) (JSOTSup, 42) 91-111; B. BURKHOLDER, Literary Patterns and God's Sovereignty in Daniel 4 // Direction 16 (1987) 45-54; W. H. SHEA, Further Literary Structures in Daniel 2-7: An Analysis of Daniel 4 // Andrews University Seminary Studies 23 (1985) 193-202; A. A. Di Lella, Daniel 4:7-14: Poetic Analysis and Biblical Background // Mélanges bibliques et orientaux en l'honneur de M. Henri Cazelles / Ed. A. Caquot, M. Delcor (Kevelaer, 1981) (AOAT, 212) 247-258; L. F. HartMAN, The Great Tree and Nabuchodonosor's Madness // The Bible in Current Catholic Thought / Ed. J. L. McKenzIE (New York, 1962) 75-82. 
phic connotation of the tree imagery. Cumulative evidence leads to the tentative conclusion that the tree story employs the language and images and develops the ideology of early exilic and postexilic traditions that portray Adam as the equivalent of ancient Near Eastern cultic statues (as the replacement of YHWH's cultic statue of the First Temple no longer extant) and as the only legitimate alternative to idol worship. The imagery of the enormous tree and its iconic connotations originate in the Mesopotamian concept of the messutree, the tree that supplies the flesh of the gods, the material of their statuary presence.

\section{The Text}

Chapter 4 of Daniel is preserved in one Aramaic and two Greek versions. ${ }^{2}$ The Aramaic text, which seems to be the language of the autograph, is not attested at Qumran, except for verses 29-30 in 4QDan'. The earliest manuscript of the Aramaic texts (henceforth MT) is still the Leningrad Codex B 19A, dating from 1008 or 1009 C.E.

There are two extant Greek versions: the Old Greek version (henceforth OG) preserved in two manuscripts ${ }^{3}$ and supported by a seventh century literal Syriac translation, ${ }^{4}$ and the version attributed to Theodotion (henceforth Th). A text close to the version attributed to Theodotion is attested in the New Testament, which suggests that the textual tradition circulated before the end of the Second Temple period. In chapter 4 Th generally follows MT against OG, as it does in chapters 5 and 6 . In the rest of the book Th is closer to OG than to MT.

The MT/Th version of the tree story reads:

${ }^{2}$ On the textual history of Daniel 4, see especially T. McLAY, It's a Question of Influence: The Theodotion and Old Greek Texts of Daniel // Origen's Hexapla and Fragments (Tübingen, 1998) 231-254; O. MunNICH, Les versions grecques de Daniel et leurs substrats semitiques // VIII Congress of the International Organization for Septuagint and Cognate Studies / Ed. L. GreEnspoon, O. Munnich (Atlanta, 1995) 291-308; A. A. Di Lella, The Textual History of Septuagint-Daniel and TheodotionDaniel // The Book of Daniel: Composition and Reception... Vol. 2. 586-607; E. CHARLES UlRICH, The Text of Daniel in the Qumran scrolls // The Book of Daniel: Composition and Reception... Vol. 2. 573-585; J. Lust, The Septuagint Version of Daniel 4-5 // Book of Daniel in the Light of New Findings... 39-53.

${ }^{3}$ The relevant portions of Papyrus 967 (second or early third century C.E.), discovered in Egypt in 1931 and regrettably divided among three current locations, Dublin, Cologne, and Barcelona, were published in F. G. KEnYon, The Chester Beatty Biblical Papyri (London, 1937) Fasc. 7. 17-38; W. Hamm, Der Septuaginta-Text des Buches Daniel Kap 3-4 (Bonn, 1977) (PTA, 21). The Barcelona fragment does not contain any texts from chapter 4 . The Codex Chisianus or MS 88 (ninth through eleventh centuries C.E.) is the source of the text in A. RAHLFS, Septuaginta (Stuttgart, 1935 and reprints).

${ }^{4}$ A. M. Ceriani, Codex syro-hexaplaris ambrosianus (Milan, 1874). 


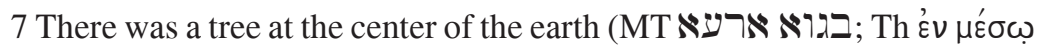

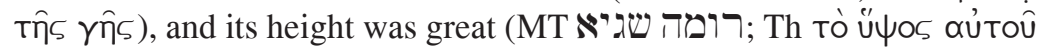
по入и́). 8 The tree grew great and strong, its height reached to heaven

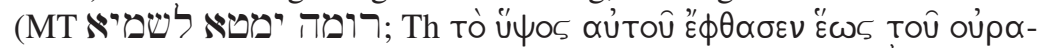
voû), and its sight to the ends of the whole earth (MT רחזותה לםופ

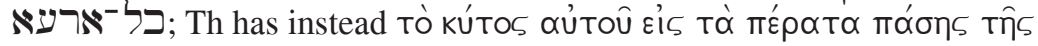
$\gamma \bar{\eta} \zeta) .{ }^{5} 9$ Its foliage was beautiful, its fruit abundant, and it provided food for all. The animals of the field found shade under it, the birds of the air nested in its branches, and from it all living beings were fed. 10 I continued looking, in the visions of my head as I lay in bed, and there was a holy watcher, coming down from heaven. $11 \mathrm{He}$ cried aloud and said: «Cut down the tree and chop off its branches, strip off its foliage and scatter its fruit. Let the animals flee from beneath it and the birds from its branches. 12 But leave its stump and roots in the ground, with a band of iron and bronze, in the tender grass of the field. Let him be bathed with the dew of heaven, and let his lot be with the animals of the field in the grass of the earth. 13 Let his mind be changed from that of a human (MT לבユה

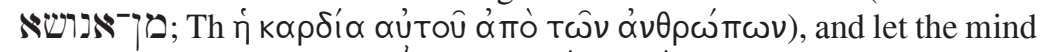

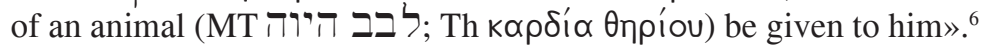

OG preserves a version very much different from $\mathrm{MT} / \mathrm{Th}^{7}$ :

10 Behold an enormous tree seen throughout the world. 11 Its appearance was great, and no other had its likeness. 12 Its branches were about thirty stadia in length, and all the animals of the earth found shade under it, and within it nested all the birds of heaven. Its fruit was abundant and good and fed all living things. And its appearance was great. Its top reached to heaven and its trunk to the clouds, filling the space under heaven; the sun and the moon abode in it and illumined all the earth. I watched in my sleep and behold an angel was sent in power from heaven and spoke and said [to him- MS 88]: «Cut it and destroy it. The Most High commanded to uproot and render it useless». He also said: «Leave one of its roots in the ground, so that it may eat grass like an ox with the animals of the earth on mountains. And from the dew of heaven its body will change and with them it will pasture for seven years, until it knows that the Lord of heaven has dominion over all the things in heaven and over all those on earth, and does with them what he pleases». ${ }^{8}$

${ }^{5}$ The Greek translation raises several issues at this point. It is not clear what prompted the use of kútos.

${ }^{6}$ This and subsequent translations from the Hebrew Bible follow the text of NRSV.

${ }^{7}$ For a thorough review of the differences between the two main versions of Daniel 4, see especially Henze, Madness, 24-33.

${ }^{8}$ This is my own translation of the text in RAHLFS, Septuaginta... and J. ZIEGLER, Septuaginta: Vetus Testamentum Graecum 16/2: Susana, Daniel, Bel et Dagon (Göttingen, 1954). 


\section{Redaction History}

The prevailing consensus in current scholarship is that chapters 2-6 of Daniel constitute an Aramaic unit originally independent from the Hebrew section of the book. ${ }^{9}$ This unit itself is most probably a collection and synchronization of originally independent stories. In its extant forms, the Aramaic unit is commonly dated to the Hellenistic period that precedes the persecution of Antiochus Epiphanes (i.e., between 330 and 175 B.C.E), with scholarly preferences ranging throughout this period. ${ }^{10}$ John Collins notes that «the only datum in the tales that requires so late a date», namely in the Hellenistic period, is the reference to the four kingdoms in Daniel 2. ${ }^{11} \mathrm{Al}-$ though the Aramaic unit only names Babylonian (chs. 2-5), Median (6:1), and Persian kingdoms (6:28), the four kingdoms of Daniel 2 most probably also include the Hellenistic kingdom. ${ }^{12}$ However, the reference to a fourth kingdom constitutes a very weak basis for dating. Reinhard G. Kratz makes a very good point that the reference to the four kingdoms could be secondary and that the Aramaic unit could well be dated to the Persian period..$^{13}$ Martin

${ }^{9}$ On the unity of chapters 2-6, see especially J.-W. Wesselius, Discontinuity, Congruence, and the Making of the Hebrew Bible // SJOT 13 (1999) 24-77; IDEM, The Writing of Daniel // The Book of Daniel: Composition and Reception... Vol. 2. 291-310; J. J. Collins, Daniel (Minneapolis, 1993) (Hermeneia) Esp. 24-38; P. S. DAVID, The Composition and Structure of the Book of Daniel: A Synchronic and Diachronic Reading (PhD diss., Katholicke Universiteit, 1991); Lust, The Septuagint Version of Daniel 4-5...; O. Munnich, Texte Massorétique et Septante dans le Livre de Daniel // The Earliest Text of the Hebrew Bible: The Relationship Between the Masoretic Text and the Hebrew Base of the Septuagint Reconsidered / Ed. A. SCHENKER (Atlanta, 2003) (SCS, 52) 93-120; R. T. McLAY, The Old Greek Translation of Daniel Chapters 4-6 and the Formation of the Book of Daniel // VT [forthcoming]).

${ }^{10}$ For dating, see Henze, Madness... 10-11; G. Hölscher, Die Entstehung des Buches Daniel // ThStK 92 (1919) 113-138; Collins, Daniel... 24-38; R. AlberTz, The Social Setting of the Aramaic and Hebrew Book of Daniel // The Book of Daniel: Composition and Reception... Vol. 1. 171-204; E. HAAG, Die Errettung Daniels aus der Löwengrube: Untersuchungen zum Ursprung der biblischen Daniel-tradition (Stuttgart, 1983) (SBS, 10). A. Lenglet (La Structure littéraire de Daniel 2-7 // Bib 53 (1972) 169-190) is exceptional in arguing that chapters 4 and 5 address the kingdom of Antiochus Epiphanes. Henze (Madness... 10-11) opts for «a pre-Maccabean context, possibly the third century, with even older material incorporated into them [the Aramaic tales]».

${ }^{11}$ Collins, Daniel... 36.

12 Ibid. 166-170.

${ }^{13}$ R. G. KRATZ, Translatio Imperii: Untersuchungen zu den aramäischen Danieler-zählungen und ihrem theologiegeschichtlichen Umfeld (Neukirchen-Vluyn, 1991) (WMANT, 63) 134-148. 
Noth, while accepting the reference to the Hellenistic kingdoms as central to chapter 2, contends that early nuclei of the Aramaic unit could date from the last decades of the fourth century B.C.E. ${ }^{14}$

Current scholarly consensus allows for the probability that the stories of chapters 2-6 have a long pre-Hellenistic history of independent circulations and that they were only finalized and collected in the first half of the Hellenistic period..$^{15}$ In particular the extant textual versions of chapter 4 reflect a sinuous and extensive circulation of the tree story. It has long been proposed that chapter 4 evolved from a sixth century tradition about Nabonidus, and not about Nebuchadnezzar, to which attest several Babylonian documents (the Nabonidus Chronicle, Verse Account of Nabonidus, and the stelae from Harran). ${ }^{16}$

\section{The Mēsu-Tree}

The scholarship of Daniel 4 has previously noted the connection of the text to the generic religious symbol of the cosmic tree. ${ }^{17}$ However, the symbol is an all-embracing umbrella term for concepts of enormous diversity from different cultural and historical environments, concepts far too complex and diverse to submit to such generalization without inevitable dilution. The association of the tree of Daniel 4 with this generic concept fails to contextualize the biblical narrative. The context for the tree imagery of Daniel 4 might be sought in earlier biblical and ancient Near Eastern sources.

The most commonly evinced literary parallel to Daniel 4 is Ezekiel $31 .{ }^{18}$ Ezek 31:2-14 contains a strikingly similar depiction of a tree, which is associated to the Egyptian pharaoh: ${ }^{19}$

2. Mortal, say to Pharaoh king of Egypt and to his hordes: Whom are you like in your greatness? 3. Consider Assyria, a cedar of Lebanon, with fair branches and forest shade, and of great height, its top among the clouds.

\footnotetext{
${ }^{14}$ M. Noth, Zur Komposition des Buches Daniel // ThStK 98/99 (1926) 143-163.

${ }^{15}$ Henze, Madness... 11; Collins, Daniel... 38.

${ }^{16}$ Texts in ANET. 305-307, 312-315; S. SMith, Babylonian Historical Texts Relating to the Capture and Downfall of Babylon (London, 1924) 22-123; C. J. GADD, The Harran Inscriptions of Nabonidus // AnSt 8 (1958) 35-92. The materials about Nabonidus are reviewed in Henze, Madness... 57-63. For the connection of Daniel 4 with Nabonidus traditions, see P. RIESSLER, Das Buch Daniel (Stuttgart-Wien, 1899) 43; Collins, Daniel... 217-219; Henze, Madness... 52-73; Coxon, Another Look... 216-218; Косн, Gottes Herrschaft... 94-98.

${ }^{17}$ Collins, Daniel... 223.

${ }^{18}$ Ibid.; Hartman, Great Tree... 78-79; Coxon, Great Tree... 94-96; Henze, Madness... 77-79.

${ }^{19}$ For a thorough comparison between Daniel 4 and Ezekiel 31, see H. Kvanvig, Roots of Apocalypticism: The Mesopotamian Background of the Enoch Figure and the Son of Man (Neukirchen, 1988) (WMANT, 61) 476-480.
} 
4. The waters nourished it, the deep made it grow tall, making its rivers flow around the place it was planted, sending forth its streams to all the trees of the field. 5. So it towered high above all the trees of the field; its boughs grew large and its branches long, from abundant water in its shoots. 6. All the birds of the air made their nests in its boughs; under its branches all the animals of the field gave birth to their young; and in its shade all great nations lived. 7. It was beautiful in its greatness, in the length of its branches; for its roots went down to abundant water. 8 . The cedars in the garden of God could not rival it, nor the fir trees equal its boughs; the plane trees were as nothing compared with its branches; no tree in the garden of God was like it in beauty. 9. I made it beautiful with its mass of branches, the envy of all the trees of Eden that were in the garden of God. 10. Therefore thus says the Lord GOD: Because it towered high and set its top among the clouds, and its heart was proud of its height, 11. I gave it into the hand of the prince of the nations; he has dealt with it as its wickedness deserves. I have cast it out. 12. Foreigners from the most terrible of the nations have cut it down and left it. On the mountains and in all the valleys its branches have fallen, and its boughs lie broken in all the watercourses of the land; and all the peoples of the earth went away from its shade and left it. 13. On its fallen trunk settle all the birds of the air, and among its boughs lodge all the wild animals. 14. All this is in order that no trees by the waters may grow to lofty height or set their tops among the clouds, and that no trees that drink water may reach up to them in height. For all of them are handed over to death, to the world below; along with all mortals, with those who go down to the Pit.

Biblical scholarship has also previously noted the connection of the Book of Ezekiel to the Mesopotamian Book of Erra, dated between the eleventh and the eighth century B.C.E., with a general preference in current scholarship for a later date within this period. ${ }^{20}$ In tablet I of the poem, the god Erra sets out for Babylon, one of the cities he wants to destroy, to enquire Marduk

${ }^{20}$ For this connection, see D. BoDI, The Book of Ezekiel and the Poem of Erra (Freiburgh-Göttingen, 1991) (OBO, 104); IDEM, Le Livre d'Ezechiel et le Poeme d'Erra // ETR 68 (1993) 1-23; B. MAARsingh, Das Schwertlied in Ez 21,13-22 und das Erra-Gedicht // Ezekiel and His Book. Textual and Literary Criticism and Their Interrelation / Ed. J. Lust (Leuven, 1986) 350-358; M. ANBAR, Une nouvelle allusion à une tradition babylonienne dans Ézéchiel (XXII 24) // VT 29 (1979) 352-353; R. FranKENA, Kanttekeningen van een Assyrioloog bij Ezechiël (Leiden, 1965). For the Poem of Erra, see also L. CAGni, The Poem of Erra (Malibu, 1977); IDEM, L'Epopea di Erra // StSem 34 (1969) 192-195; IDEM, L'Epopea di Erra (Roma, 1969); D. O. EdZARD, Irra (Erra) - Epos // Reallexikon der Assyriologie / Ed. E. Ebeling, B. Meissner (Berlin, 1928-) Vol. 5. 168-169; W. G. LAMBERT, Review of F. Gössmann, Das Era-Epos // AfO 18 (1957-1958) 389-400; J. BотTÉRo, Antiquités assyro-babyloniennes (l'Épopée d'Erra) // Annuaire EPHE 4 (1977-1978) 107-164. For dating, see Bod, The Book of Ezekiel and the Poem of Erra... 54-56; CAGNI, L'Epopea di Erra... 37-45. 
about the tarnished state of the latter's statue and thus to incite the god of Babylon to either abandon his city or to join Erra in destroying it:

$\mathrm{He}$ [Erra] entered Esagila, palace of heaven and earth, and stood in front of him [Marduk].

He made his voice heard and spoke to the king of gods,

«Why does the finery, your lordship's adornment which is full of splen dour like the stars of heaven, grow dirty?

Your crown of your lordship which made E-halanki shine like E-temenanki - its surface is tarnished!» (Erra I 125-128)

Marduk reminds Erra that his previous abandonment of his statue and of the city caused a catastrophic flood. His statue suffered damage and he had to summon the fire god, Gerra, to refurbish it, before he would resume his residence in it:

As for the finery which had been pushed aside by the Flood, its surface dulled:

I directed Gerra to make my features radiant, and to cleanse my robes.

When he had made the finery bright, and finished the work, I put on my crown of lordship and went back to my place.

My features were splendid, and my gaze was awesome!

(As for) the people who were left from the Flood and saw the result of my action,

Should I raise my weapons and destroy the remnant?

I made those (original) Craftsmen go down to the Apsu, and I said they were not to come back up.

I changed the location of the $m \bar{e} s u$-tree (and of) the elmēsu-stone, and did not reveal it to anyone.

Now, concerning that deed which you have said you will do, Warrior Erra,

Where is the $m \bar{e} s u$-wood, the flesh of the gods, the proper insignia of the King of the World,

The pure timber, tall youth, who is made into a lord,

Whose roots reach down into the vast ocean through a hundred miles of water, to the base of Arallu,

Whose topknot above rests on the heaven of Anu? ...

(Erra I 140-153) ${ }^{21}$

The $m \bar{e} s u$-tree ${ }^{22}$ functions as the «flesh of the gods», concept that, as Angelika Berlejung notes, «im Kontext der Herstellung von Kultbirdern ist...

${ }^{21}$ Translation from S. DALlEy, Myths from Mesopotamia (Rev. ed., Oxford, 2000) 290-291.

${ }^{22}$ On the $m \bar{s}$ su-tree, see W. von SodEn, Akkadisches Handwörterbuch I-III (Wiesbaden, 1965-1981) 647a; A. L. OppenheIM et al. (eds.), The Assyrian Dictionary of the Oriental Institute of the University of Chicago (Chicago, 1956-) M II 33-34. 
haüfig belegt. Er bezeichnet dann jeweils das Material, aus dem die Bilder hergestellt warden». ${ }^{23}$

Another similar depiction of the $m \bar{s} s u$-tree is extant in STT 199, a tablet dated to the seventh century B.C.E.: ${ }^{24}$

13. [Incantation:] as you come out, as you come out in greatness from the forest:

14. as you come out from the pure forest, wood of the pure forest...

29. as you come from the pure forest of $m \bar{e} s u^{25}$-trees, wood of the pure forest of $m \bar{e} s u^{26}$-trees,

30. bright wood, (like) the spring of a stream, which is born in the pure Heavens, spreads out on the clean earth,

31. your branches grow up to Heaven, Enki makes your root drink up pure water from the Underworld. ${ }^{27}$

The ensuing text describes the process of the making of the statue out of the enormous tree.

One central feature in the descriptions of the $m \bar{e} s u$-tree is its enormity, which is meant to accommodate the immense size of the god:

Die Materialien der Mardukstatue verbinden in sich kosmische Dimensionen (Himmel, Erde, Unterwelt) und bringen bestimmte Eigenschaften mit, die sie mit dem Gott des Kultbildes verbinden und mit ihm gemeinsam haben. ${ }^{28}$

Several main features of the Mesopotamian mзsu-tree emerge in the depiction of the pharaonic tree in Ezekiel 31:

1. The latter is similarly enormous.

2. It feeds on abundant underground waters.

3. Its top reaches the clouds of heaven.

4. It has a conspicuous and prominent location among the other trees of Eden (Erra I 148-153 suggests a similar prominent location of the mēsutree).

Furthermore, the context of Ezekiel 31 suggests that the pharaonic tree functions as an iconic presence of the divine similarly to the $m \bar{e} s u$-tree. Eze-

${ }^{23}$ A. Berlejung, Die Theologie der Bilder. Herstellung und Einweihung von Kultbildern in Mesopotamien und die alttestamentliche Bilderpolemik (Göttingen, 1998) 150, n. 821.

${ }^{24} \mathrm{Ch}$. Walker, M. Dick, The Induction of the Cult Image in Ancient Mesopotamia. The Mesopotamian Mīs Pî Ritual (Helsinki, 2001) (The Neo-Assyrian Text Corpus Project) 28.

${ }^{25}$ I preferred a transliteration in accordance to CAD M II 34.

${ }^{26}$ I preferred a transliteration in accordance to CAD M II 34.

${ }^{27}$ Translation from W ALKER, Dick, The Induction of the Cult Image... 119-120.

${ }^{28}$ Berlejung, Die Theologie der Bilder... 152. 
kiel 31 is in evident parallelism with Ezekiel $28 .{ }^{29}$ The two stories share several elements. Both are diatribes against foreign nations, namely the king of Tyre and the pharaoh, who is compared to the tree that Assyria represents. Both the tree-Assyria and the king of Tyre are placed in Eden, «the garden of God» (םיה גיה 31:8-9; 28:12). Both are beautiful (31:3, 8-10; 28:12).

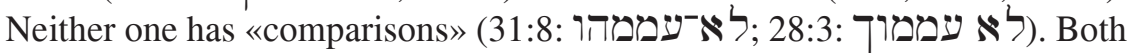
have prominent positions in the garden of God. Both commit the mistake of hubris. ${ }^{30}$ Both «elevate» themselves (31:10: גבהת מגבה 28:2) in their hearts (ユל, ニニ ל: 31:10;28:2,6). The divine reprimands in both cases start with the same formula. ${ }^{31}$ The punishment of both is carried out by «foreigners, the most ruthless of nations» (זרים עריצי גוים slain by the sword (חל 31:18; 28:8,9) among the uncircumcised (מרים (ם $31: 18 ; 28: 8,9)$ and are taken down to the pit $(31: 14 ; 28: 8){ }^{32}$

Moreover, the king of Tyre claims divine status, claims to be a «god» (א: 28:2,9). The swift divine correction reminds the king that he is a human

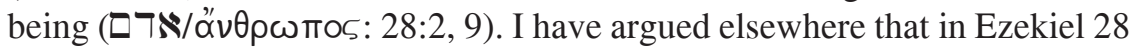
the king of Tyre functions as the cultic statue of YHWH and that Ezekiel 28

${ }^{29}$ Ezekiel 28 has received an extensive attention from modern scholarship. To cite only a few studies: D. Launderville, O.S.B., Ezekiel's Cherub: A Promising Symbol or a Dangerous Idol? // CBQ 65 (2004) 165-183; J. E. MilLER, The Maelaek of Tyre (Ezekiel 28, 11-19) // ZAW 105 (1994) 497-501; WILson, The Death of the King of Tyre...; N. C. HABEL, Ezekiel 28 and the Fall of the First Man // Concordia Theological Monthly 38 (1967) 516-524; K. YARON, The Dirge over the King of Tyre // ASTI 3 (1964) 28-57; H. G. MAY, The King in the Garden of Eden: A Study of Ezekiel 28:12-19 // Israel's Prophetic Heritage: Essays in Honor of James Muilenburg / Ed. B. Anderson, W. Harrelson (New York, 1962) 166-176; A. J. Williams, The Mythological Background of Ezekiel 28:12-19? // BTB 6 (1976) 49-61; K. JEPPESEN, You are a Cherub, but no God! // SJOT 1 (1991) 83-94; O. LoRETz, Der Sturz des Fürsten von Tyrus (Ez 28,1-19) // UF 8 (1976) 455-458; J. BARR, «Thou art the Cherub»: Ezekiel 28.14 and the Postexilic Understanding of Genesis 2-3 // Priests, Prophets and Scribes. Essays on the Formation and Heritage of Second Temple Judaism in Honour of Joseph Blenkinsopp / Ed. E. Ulrich, J. W. Wright, R. P. Caroll, Ph. R. DAvies (Sheffield, 1992) (JSOTSup, 149) 213-223.

${ }^{30}$ D. I. BLOCK, The Book of Ezekiel. 2 vols (Grand Rapids-Cambridge, 1997, 1998) Vol. 2. 119-125.

${ }^{31}$ Ibil. 180, n. 7.

${ }^{32}$ It has been repeatedly argued that vv. 5, 9-18 are later additions to an original poem that comprised vv. 2-4, 6-8. See thus HöLSCHER, Hesekiel... 152-155; BLOCK, The Book of Ezekiel... Vol. 2. 178-179. The deletion of vv. 5 and 9 is widely accepted (ZimMerLi, Ezekiel... Vol. 2. 142-146; WeVERs, Ezekiel... 234) but the authenticity of vv. 10-18 is less disputed. Nevertheless, the parallelism of the passage with Ezekiel 28 transpires even through verses that are commonly undisputed, especially vv. 3 and 8 . 
employs idol imagery and language to construct an iconic anthropology, also evident in the Priestly ideology (Gen 1:26). ${ }^{33}$ It has been previously noted in recent scholarship that the destruction of the First Temple and of its statue ${ }^{34}$ forced Judah to reassess and revise its conceptions of divine presence/absence. ${ }^{35}$ Exilic and post-exilic texts and artifacts attest to the fact that the

${ }^{33}$ See my article «YHWH's Cultic Statue after 597/586 B.C.E.: A Linguistic and Theological Reinterpretation of Ezek 28:12», forthcoming in The Catholic Biblical Quarterly.

${ }^{34}$ Biblical scholarship has increasingly acknowledged the fact that monarchic Israel and Judah were not aniconic. While current scholarship still favors the concept of «empty space aniconism», it allows more and more for the probability that ancient Judah was not devoid of cultic images and that it worshipped a cultic statue of Yhwh in the First Temple. For the concept of «empty space aniconism» and on the issue of a statue of Yhwh in the First Temple, see A. H. J. GunnEweg, Bildlosigkeit Gottes im Alten Testament // Henoch 6 (1984) 257-270; B. GladiGow, Präsenz der Bilder-Präsenz der Götter // Visible Religion 4-5 (1985-1986) 114-133; B. BECKING, Assyrian Evidence for Iconic Polytheism in Ancient Israel? // The Image and the Book: Iconic Cults, Aniconism, and the Rise of Book Religion in Israel and the Ancient Near East / Ed. K. van DER Toorn (Leuven, 1997) 157-171; H. NIEHR, In Search of YHWH's Cult Statue in the First Temple // The Image and the Book... 73-96; I. Cornelius, The Many Faces of God: Divine Images and Symbols in Ancient Near Eastern Religions // The Image and the Book... 21-43; Ch. UeHLIngER, Anthropomorphic Cult Statuary in Iron Age Palestine and the Search for Yahweh's Cult Images // The Image and the Book... 97-155; IDEM, Israelite Aniconism in Context // Bib 77 (1996) 540-549; M. Dietrich, O. Loretz, «Jahwe und seine Aschera»: Anthropomorphes Kultbild in Mesopotamien, Ugarit und Israel. Das biblische Bilderverbot (Münster, 1992) (UBL, 9); N. NA'Aman, No Anthropomorphic Graven Image: Notes on the Assumed Anthropomorphic Cult Statues in the Temples of YHWH in the Preexilic Period // UF 31 (1999) 391-415; T. S. LEWIS, Divine Images: Aniconism in Ancient Israel // JAOS 118 (1998) 36-53; B. B. SchmIDT, The Aniconic Tradition: On Readings Images and Viewing Texts // The Triumph of Elohim; From Yahwisms to Judaisms / Ed. D. V. EDELMAN (Grand Rapids, 1996) 75-105; T. N. D. MetTinger, No Graven Image? Israelite Aniconism in Its Ancient Near Eastern Context (Stockholm, 1995) (ConBOT, 42); IDEM, Aniconism: A West Semitic Context for the Israelite Phenomenon? // Ein Gott allein? JHWH-Verehrung und biblischer Monotheismus im Kontext der israelitischen und altorientalischen Religionsgeschichte / Eds. W. Dietrich, M. Klopfenstein (Freiburg-Göttingen, 1994) 159-178; IDEM, The Veto on Images and the Aniconic God in Israel // Religious Symbols and Their Functions / Ed. H. BIEZAIs (Stockholm, 1979) (SIDA, 10) 15-29; IDEM, Israelite Aniconism: Developments and Origins // The Image and the Book... 173-204; K. VAN DER ToORN, The Iconic Book Analogies Between the Babylonian Cult of Images and the Veneration of the Torah // The Image and the Book... 229-248; J. C. DE Moor, The Rise of Yahwism (Leuven, 1990) 170-172.

${ }^{35}$ For the issue of the presence/absence of Yhwh, central to exilic and postexilic ideologies, see especially J. F. KuTsko, Between Heaven and Earth. Divine Presence 
expectations for the iconic presence of YHWH, expectations innate in the ancient Near Eastern ideological context, ${ }^{36}$ survived the destruction of the temple. ${ }^{37}$ In contrast to the Deuteronomistic circles, which so radically substituted the preexilic iconic ideology with an anti-iconic šem-theology, ${ }^{38}$ in priestly circles emerged a theomorphic anthropology, which defined Adam's special connection to the deity by means of selem and demût (Gen 1:26), terms generally used to denote statues of gods (e.g., Num 33:52; 1 Sam 6:5;

and Absence in the Book of Ezekiel (Winona Lake, IN, 2000) (BJSUC, 7); J. BLENKINsopp, History and Prophecy in Ancient Israel (Philadelphia, 1983) 197; G. A. ANDERson, Sacrifices and Offerings in Ancient Israel: Studies in Their Social and Political Importance (Atlanta, 1987) (HSM, 41) 93. For this concern in Ezekiel 28, see especially LAUNDERVILLE, Ezekiel's Cherub...

${ }^{36} \mathrm{M}$. WeINFELD notes so succinctly that in the ancient Near Eastern world «having gods meant having idols» (Deuteronomy 1-11 (New York, 1991) (AB, 5) 291). The only means of divine presence in a temple was the cult representation of the deity. See thus A. Berlejung, Washing the Mouth: The Consecration of Divine Images in Mesopotamia // The Image and the Book... 45-72, here 61; NIEHR, YHWH's Cult Statue... 77; vAN DER ToORN, Iconic Book... 235. An imageless temple would have been therefore as meaningless as a house without habitants. The temple was not complete until the god had taken its place in it. After the completion of the building followed a ritual referred to as «causing the deity to dwell in it» (NIEHR, YHWH's Cult Statue... 78). The making of the idol and its placement in the temple constituted the completion of the construction of the temple. The two acts are never fully independent. E.g., Sennacherib is called in one text «he who made the image of his god and built his (the god's) favorite temple» (CAD E 200a, OIP 2.146:31). As Avigdor Hurowitz notes, «if the dedication of a house is accomplished by its builder taking up residence in it, so a temple, which is primarily conceived of as a divine dwelling place, is dedicated by its divine resident taking up residence within it» (A. HuRowITz, I Have Built You an Exalted House. Temple Building in the Bible in Light of Mesopotamian and Northwest Semitic Writings (Sheffield, 1992) (JSOTSupp, 115) 267).

${ }^{37}$ Cf. Psalm 115:2-8; Isa 40:18-19 (= Isa 46:5-6); 42:8-9; Jer 2:26-27; 10:14-16.

${ }^{38}$ In this ideology, the place of worship becomes only a dwelling for the ultimately unconfined and immaterial name of God (e.g., 1 Kgs 8:16-20,29,44,48; 2 Sam $7: 13$ ). Weinfeld, one of the main analysts of the šêm ideology, summarizes: «The deuterenomic school used this phraseology in a very consistent manner and never made the slightest digression from it. There is not one example in the deuteronomic literature of God' dwelling in the temple or the building of a house for God. The temple is always the dwelling of his name, and the house was built for his name» (WEINFELD, Deuteronomy and the Deuteronomistic School... 193). For the Deuteronomic circles YHWH dwells physically in a secluded heaven (1 Kgs 8:27-49; Deut $26: 15 ; 33: 26)$. YHWH's presence on earth is exclusively mediated through his name. The Sinai event is revised and purged of any reference to the form or bodily appearance of YHWH (Deut 4:12). YHWH spoke from heaven and not from the top of the mountain and the contact with him was not visual, but auditory (cf. Deut 4:12,32,36; $5: 4,22-23)$. 
2 Kgs 11:18; Ezek 7:20; 16:17; 23:24; Amos 5:26; see also Isa 40:18-19a and 46:5-6). Previous scholarship has thus remarked that the Priestly ideology regarded Adam as the equivalent of a pagan cult statue or idol, a legitimate channel for the worship of YHWH. ${ }^{39}$

The Book of Ezekiel as a whole similarly constitutes an assessment of the cataclysm of the destruction of the temple and a reformulation of the divine presence amidst the exiled Judah. ${ }^{40}$ It has been previously noted in modern scholarship that the exilic concept of humanity as representation of the divine, as the selem and dem ût of YHWH (Gen 1:26), was formulated under a most probable influence from ancient Near Eastern ideologies regarding the function of royalty as images of the divine. ${ }^{41}$ In Ezekiel 28 and 31, the common ancient Near Eastern conception of the monarch as a divine statue is deconstructed and its vestigial imageries and concepts are employed to redefine humanity as theomorphic, but not isotheic. In an evident polemical engagement, the Book of Ezekiel chooses an ancient Near Eastern king to exemplify its theomorphic anthropology of evident priestly origins.

This anthropologic agenda of the Book of Ezekiel transpires throughout both chapter 28 and the tree story of Ezekiel 31. Block has noted that the «critical question» of Ezekiel 31 is «whom are you like (אל מימי דמית) in your greatness?» (v. 2, 18). ${ }^{42}$ The question closely parallels a common exilic challenge to compare YHWH with an idol: «To whom can you liken (ילימין (תדמייון) God» (Isa 40:18, 25; 46:5). Ezekiel's comparison of the pharaoh to

${ }^{39}$ See especially E. ZENGER, Gottes Bogen in den Wolken (Stuttgart, 1983) 8496; A. Angerstorfer, Hebräisch dmwt und aramäisch $d m w(t) / /$ BN 24 (1984) 30-43; Smith, Divine Form and Size... 426-427; C. L. PATTON, Adam as the Image of God: An Exploration of the Fall of Satan in the Life of Adam and Eve // SBL Seminar Papers, 1994 (Atlanta, 1994) (SBLSP, 33) 294-300; Th. PodElla, Das Lichtkleid JHWHs (Tübingen, 1996) 252-259; NIEHR, YHWH's Cult Statue... 93-94; KuTSKo, Between Heaven and Earth... 65-76. See also G. vON RAD, Genesis. A Commentary (Rev. ed., Philadelphia, 1972) 57-58; IDEM, Old Testament Theology 2 vols (New York, 1962, 1965) Vol. 2. 67-69; J. C. DE Moor, The Duality in God and Man: Gen 1:26-27 as P's Interpretation of the Yahwistic Creation Account // Intertextuality in Ugarit and Israel (Leiden, 1998) (OTS, 40) 112-125, especially 115.

${ }^{40}$ For this focus in the Book of Ezekiel, see especially KUTSKo, Between Heaven and Earth...

${ }^{41}$ For these influences, see H. WILDBERGER, Das Abbild Gottes Gen 1:26-30 // TZ 21 (1965) 245-259, 481-501; E. M. CuRTIS, Man as the Image of God in Genesis in the Light of Ancient Near Eastern Parallels (Ph.D. diss., University of Pennsylvania, 1984) Esp. 80-102, 113-119, 155-172; Ph. BIRD, «Male and Female He Created Them»: Gen 1:27b in the Context of the Priestly Account of Creation // HTR 74 (1981) 129-159; J. M. MiLlER, In the «Image» and «Likeness» of God // JBL 91 (1972) 289304; KuTsKo, Between Heaven and Earth... 60-63.

${ }^{42}$ BLOCK, The Book of Ezekiel... Vol. 2. 179. 
the Assyria-tree ${ }^{43}$ recalls the concept of the $m \bar{e} s u$-tree, which serves as material for the statues of gods, as their «flesh». ${ }^{44}$ Just like the Book of Ezekiel, the Poem of Erra, which most probably introduces the tree imagery to the Book of Ezekiel, also deals with devastations that threaten divine presences and offers paradigms of reconciliation between these cataclysmic realities and the habitation of the gods in their statues..$^{45}$

The main common features of the tree of Ezekiel 31 and of the Mesopotamian $m \bar{e} s u$-tree appear in the depiction of the tree in Daniel 4:

1. The latter is enormous.

2. Its top reaches the clouds of heaven.

3. It has the most conspicuous location in the middle of the earth.

Moreover, the sin of the tree of Daniel 4 is hubris, as is the sin of the kings in Ezekiel 28 and 31.

The probability that the tree of Daniel 4 is a development of the ancient concept of the messu-tree is further supported by the fact that its destruction reflects mutilations and desecrations of cultic images. Throughout the ancient Near East, including Canaan, statues of gods were built of wood, as the very concept of the $m \bar{e} s u$-tree suggests (cf. Isa 37:19=2 Kgs 19:18). ${ }^{46} \mathrm{De}$ structions and mutilations of divine statues are therefore commonly depicted in terms of «cutting down», «chopping off», «stripping off», «burning», and «scattering». Although extant accounts of destructions of captured divine images from the ancient Near East are scarce, ${ }^{47}$ the process, more or less homogenous, most often entailed casting the statue to the ground (cf. 1 Sam 5:3), cutting it off (גדע: Deut 7:5; 12:3; cf. Isa 10:33; ברת 1 : 1 Sam 5:4; 1 Kgs 15:13; Exod 34:13; Mic 1:7), smashing it (שבר: Ezek 6:6; Isa 21:9), burning

${ }^{43}$ The reference to Assyria is often disputed in scholarship (L. C. Allen, Ezekiel 2 vols (Dallas, 1990, 1994) Vol. 2. 122-123; BLock, The Book of Ezekiel... Vol. 2. 184). It is often proposed to emend תאשור to אשור tocypress».

${ }^{44}$ Moreover, the trees of Assyria are called in a Babylonian text «the luxurious forest of Marduk» (ANET. 307). The mēsu-tree is commonly described as a «luxuriant wood». Erra/Nergal's temple in Cuthah was called E-meslam or Meslam («luxuriant $m \bar{e} s u$-tree»). It seems that they provided the wood for divine statues.

${ }^{45}$ For this focus in the Poem of Erra, see BodI, The Book of Ezekiel and the Poem of Erra... 61-68. For the common program and focus of the Book of Ezekiel and the Poem of Erra on issues of divine presence/absence, see BoDI, The Book of Ezekiel and the Poem of Erra... 182-218.

${ }^{46}$ For wood as the material for ancient Near Eastern divine statues, see also BERLEJUNG, Die Theologie der Bilder... 120-124. For wood as material of divine statues in the Hebrew Bible, see also ibid., 365-367.

${ }^{47}$ See especially Th. BARAN, Leben und Tod der Bilder // Ad bene et fideliter seminandum. Festschrift K. Deller / Ed. G. Mauer, U. MAGEn (Kevelaer-Neukirchen-Vluyn, 1988) (AOAT, 220) 55-60; M. A. BRANDES, Destruction et mutilation de statues en Mésopotamie // Akkadica 16 (1980) 28-41. 
it (שרา: 1 Kgs 15:13; 2 Kgs 23:6; Deut 7:5, 25; 1 Chr 14:12; cf. also Mic 1:7; Isa 37:19=2 Kgs 19:18), and scattering its ashes (של 2 Kgs 23:6; Exod 32:20; Deut 7:5; 12:3). ${ }^{48}$ The mutilation and destruction of the resemblance and of the divine paraphernalia of statues was perceived as the end of their numinous character, of the presence of the gods within them.

The tree of Daniel 4 is mutilated in similar terms. The verb Y 7 p is particularly significant. It does not only refer to mutilations of human bodies (e.g., Judg 1:6; 2 Sam 4:12; 2 Kgs 18:16), but also to the mutilation of cultic objects, particularly to the chopping off of their golden layers (cf. 2 Kgs 16:17; 18:16). ${ }^{49}$ In $2 \mathrm{Kgs} 24: 13$ the term defines the destruction and desecration of the vessels of the First Temple in 597 B.C.E. Niehr suggests that the chop-

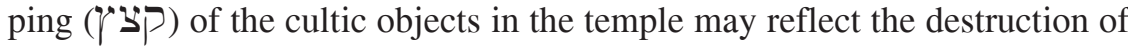
the central cultic image of YHWH in the holy of holies. ${ }^{50}$ In 2 Chr 28:24, which is built on $2 \mathrm{Kgs} 24: 14, \boldsymbol{Y}$ ק refers to a similar destructive act.

That the tree imagery of Daniel 4 has theomorphic/iconic connotations is also suggested in the opening of the story (4:1), which describes Nebuchad-

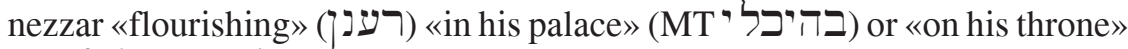

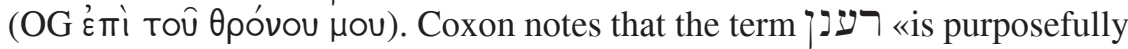
deployed in the king's opening speech to signal a subtle connection with the subject of his dream» and that «in the literary structure of the chapter it does achieve an effective double-entendre». ${ }^{51}$ Both Coxon and Matthias Henze remark that the word commonly refers to the freshness and luxuriousness of trees (Hos 14:9; Ps 52:10) and seems to allude in the context of Daniel 4 to the deuteronomistic reference to idolatry as worship «under any green/luxurious tree» (תחת כל כעיע רענן: Deut 12:2; 1 Kgs 14:23; 2 Kgs 17:10; etc.).52 The term also recalls another main feature of the $m \bar{e} s u$-tree, the wood meant to supply the statuary flesh of the gods, namely luxuriousness. The $m \bar{s} u$-tree is commonly portrayed as the most luxurious of all trees.

${ }^{48}$ See also Rassam Cylinder v.119-120; vi.62-64. Translation in ARAB. Vol. 2. 308, 310. For the probable allusion to this practice in 1 Sam 5:3-4, see W. ZwICKEL, Dagons abgeschlagener Koft (1 Sam V 3-4) // VT 44 (1994) 239-249.

${ }^{49}$ NiEHR, YHWH's Cult Statue... 91; MetTinger, Dethronement... 61; W. ThIEL, קצ // TWAT. Vol. 7. 105-106.

${ }^{50}$ «YHWH's Cult Statue», 91. Mettinger also notes that the biblical account seems to suggest «the throne was stripped of its gold plate already in 597» (Dethronement... 61). Ps 74:6-7, which mentions the breaking of the «carved work» (פרוח) and the burning of the sanctuary, might also allude to this disastrous event.

${ }^{51}$ Coxon, Great Tree... 97.

${ }^{52}$ Ibid.; HenZe, Madness... 75. 


\section{Context}

The tradition that underlies chapter 4 of Daniel, at first most probably in reference to Nabonidus, and not Nebuchadnezzar, as noted above, seems to have developed in connection with concerns about legitimate iconic worship. The Qumranic Prayer of Nabonidus, 4Q242 1, which preserves a form of this underlying tradition, ${ }^{53}$ identifies Nabonidus' punishment with idol worship:

1. The words of the p[ra]yer which Nabonidus, king of [Baby]lon, [the great ]king, prayed [when he was smitten]

2. with a bad disease by the decree of G[o]d in Teima. [I, Nabonidus, with

a bad disease]

3. was smitten for seven years and $\sin [\mathrm{ce}]$ God set [his face on me, he

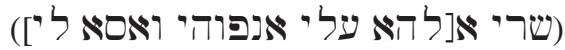

healed me]

4. and as for my sin, he remitted it. A diviner (he was a Jew fr[om among the exiles) came to me and said:]

5. «Pro[cla]im and write to give honour and exal[tatio]n to the name of G[od Most High», and I wrote as follows:]

6. «I was smitten by a b[ad] disease in Teima [by the decree of the Most High God.]

7. For seven years [I] was praying [to] the gods of silver and gold, [bronze, iron,]

8. wood, stone, clay, since [I thoug]ht that th[ey were] gods... ${ }^{54}$

The manuscript has been paleographically dated to $75-50$ B.C.E. ${ }^{55}$ Most scholars, however, would argue that 4Q242 reflects closer proximity than Daniel 4 to the early pre-Hellenistic traditions about Nabonidus on which the latter developed. ${ }^{56}$

${ }^{53}$ The prayer was first published in J. T. MiLIK, La «prière de Nabonide» at autres écrits d'un cycle de Daniel // RB 63 (1956) 407-415. Subsequent editions comprise J. J. Collins, 4QPrayer of Nabonidus // Qumran Cave 4.XVII: Parabiblical Texts. Part 3 / Ed. G. J. Brooke et al. (Oxford, 1996) (DJD, XXII) 83-93; É. PueCH, «La prière de Nabonide (4Q242) // Targumic and Cognate Studies: Essays in Honour of Martin McNamara / Ed. K. J. CAthcart, M. Maher (Sheffield, 1996) 208-227; F. M. Cross, Fragments of the Prayer of Nabonidus // IEJ 34 (1984) 260-264; F. GARCíA MARTínEZ, The Prayer of Nabonidus: A New Synthesis // IDEM, Qumran and Apocalyptic (Leiden, 1992) 116-136; P. Grelot, La prière de Nabonide (4Q Or Nab). Nouvel Essai de restauration // RevQ 9 (1978) 483-495; R. MEYER, Das Gebet des Nabonid. Eine in den Qumran-Handschriften wiederentdeckte Weisheitserzählung (Berlin, 1962).

${ }^{54}$ The text and translation are from Collins, 4QPrayer of Nabonidus... 88-89.

${ }^{55}$ Puech, La prière de Nabonide... 209; Cross, Fragments of the Prayer of Nabonidus... 260; Collins, 4QPrayer of Nabonidus... 85.

${ }^{56}$ See thus P. W. Flint, The Daniel Tradition at Qumran // Eschatology, Messianism, and the Dead Sea Scrolls / Ed. C. A. Evans, P. W. Flint (Grand Rapids, 1997) 
There are several parallelisms between Daniel 4 and 4Q242:

1. Both texts refer to a Babylonian king.

2. In both texts the king is afflicted with a serious punishment.

3 . In both texts the affliction lasts for seven years.

4. In both texts the affliction is announced by a decree.

5. As Collins notes, «in both a Jew interprets his [the king's] situation».57

6 . In both texts the king speaks in the first person. ${ }^{58}$

It has been also proposed that 4Q242 contained a dream that the diviner interprets, dream that contained a vision of a tree. ${ }^{59}$ While this proposal is highly speculative and ultimately unsolvable, lines $7-8$ place Nabonidus' affliction within a context of iconic concerns. Nabonidus' disease is not inadvertently associated with idol worship.

It is also significant that, according to Collins' reconstruction, Nabonidus' healing, the curing of idolatry, is described as imprinting with the divine

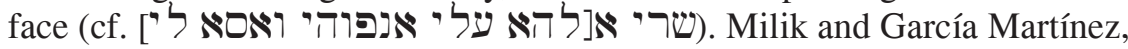
however, read שרי as a passive participle and reconstruct as «et loin [des hommes j]e fus relégué» and, respectively, «banished far from men». ${ }^{60} \mathrm{Col}-$ lins rightly points out that such reading would wrongly assume that של passive participle. Indeed, a passive participle would be spelled with final aleph or he, and not yod. "An anomalous spelling with a yod cannot be completely ruled out», he continues, «but we should assume normal spelling unless we have compelling evidence to the contrary». ${ }^{61}$ Collins consequently follows Grelot and reads 'שר as a Pael active, 'set'. While in targumic texts the phrase «to set the face on someone» is an idiom for paying attention, ${ }^{62}$ in reference to Nabonidus' "healing» from idolatry the phrase would carry evident iconic overtones. Nevertheless, this reconstruction is as speculative and hypothetical as any other. The imagery of 4Q242, whether Collins' recon-

41-60; F. M. Cross, The Ancient Library of Qumran and Modern Biblical Studies (Garden City, 1961) 123-124. It is, however, improbable that there is a direct literary relationship between Daniel 4 and 4Q242: Henze, Madness... 66-68; Cross, The Ancient Library... 123-124.

${ }^{57}$ Collins, Daniel... 217.

${ }^{58}$ For parallelisms and differences between Daniel 4 and 4Q242, see also CoLLINS, Daniel... 217-219; Henze, Madness... 64-68; Koch, Gottes Herrschaft... 8994; M. McNamara, Nabonidus and the Book of Daniel // ITQ 37 (1970) 131-149; García Martínez, The Prayer of Nabonidus... 129-130.

${ }^{59}$ See review of this position in Collins, Daniel... 218, and IDEM, 4QPrayer of Nabonidus... 87.

${ }^{60}$ García Martínez, The Prayer of Nabonidus... 120; Milik, La «prière de Nabonide»... 408.

${ }^{61}$ Collins, 4QPrayer of Nabonidus... 90.

${ }^{62}$ Ibid. 
struction is accurate or not, focuses on concerns regarding legitimate channels of iconic worship. ${ }^{63}$

A similar focus on legitimate channels of iconic worship emerges throughout the context of Daniel 4. All three stories that encircle Daniel 4, namely Daniel 2, 3, and 5, converge on iconic concerns. In Daniel 2 Nebuchadnezzar

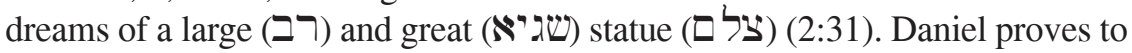
know the king's dream and interprets it. The story ends with Nebuchadnezzar worshipping Daniel: he «fell prostrate and worshipped (וכל על-אנפוהי) (ול דני אל סגד Daniel and ordered that sacrifice and incense be offered to him» (2:46). Nebuchadnezzar's behavior is, to say the least, striking. The more striking this act is as it is followed in chapter 3 with a story about Nebuchadnezzar imposing on his subjects the cult of a newly built idol of enormous proportions $(3: 1)$.

Daniel 4 share with chapters 2 and 3 a focus on external appearances; the subjects in all of these narratives share a common feature, namely enormity. Both stories preceding Daniel 4 mention iconic venerations in evident interconnection: in 2:46 Nebuchadnezzar worships Daniel himself, while throughout chapter 3 Nebuchadnezzar tries to impose the worship of an idol. Crispin Fletcher-Louis has noted that the close similarity between the worship of Adam by angels in Life of Adam and Eve 12-16 and Daniel 3 suggests that «the former owes its genius to the early Hellenistic period when Daniel 3 was written» and that both texts attest to an early tradition about the iconicity of humanity. ${ }^{64}$

Daniel 5 contains a similar concern with idol worship. In what the chapter presents as one act (cf. 5:4), Nebuchadnezzar's son, Belshazzar, and his court defile the vessels of the First Temple and worship idols (5:1-4). It is significant that Belshazzar's idolatrous act is directly associated with Nebuchadnezzar's story in chapter 4.

\section{Theomorphism versus Theriomorphism or Angelomorphism as the Decadence of Humanity}

The focus of the whole context of Daniel 4 on issues of legitimate iconic worship leads to further possible iconic connotations of the imageries of Daniel 4. Several scholars have contented that the animal deformation of the tree constitutes a tradition that was associated with the tree dream at later stages in the development of Daniel $4 .{ }^{65}$ It is impossible to determine the stage at

${ }^{63}$ It is equally speculative to read with PUECH in the missing space a reference to a transformation into an animal (La «prière de Nabonide»... 211).

${ }^{64}$ C. Fletcher-Louis, All the Glory of Adam. Liturgical Anthropology in the Dead Sea Scrolls (Leiden-Boston-Köln, 2002) (STDJ, 42) 101-103.

${ }^{65}$ Collins, Daniel... 219; Coxon, Great Tree... 99-100; 
which the story of Daniel 4 incorporated the tradition. Collins rightfully notes that reading the tradition within the lacunae of 4 Q242 is unfounded. ${ }^{66}$ It is evident, however, that the incorporation, present in both versions of Daniel 4, occurred in the third century B.C.E. or earlier.

Nebuchadnezzar's theriomorphism has been generally read through the lens of ancient Near Eastern depictions of human heroes with animal traits or life-habits. ${ }^{67}$ In parallelism to these depictions, Nebuchadnezzar's theriomorphism would symbolize a reversal of the development of humankind from its original animalic state. However, the concept that humanity was in its original state animalic does not appear anywhere in the Hebrew Bible, albeit suggested in the preexilic creation story. Second, the Priestly ideology behind the first creation story is very emphatic about the fact that humanity bears a physical resemblance to YHWH. Daniel 4 is indebted to this ideology in its concern with legitimate iconic worships.

The concern of the whole section Daniel 2-5 with legitimate channels of iconic worship evinces another connotation of Nebuchadnezzar's theriomorphism. In the terms of the parable, by becoming theriomorphic, Nebuchadnezzar loses his dendromorphism-theomorphism and appropriates the subordinate status of the ones who subsist on the tree. In verse 9 the tree is mentioned to have provided «food for all. The animals of the field found shade under it, the birds of the air nested in its branches, and from it all living beings were fed». In his theriomorphism, Nebuchadnezzar ceases to function as a divine image and becomes one of those who merely subsist on the theomorphism of the image.

In the terms of the parable the creatures who subsist on the iconicity of humanity are not humans. Concurrent and subsequent traditions about the iconic function of Adam suggest that these creatures stand for angels. Several studies have explored the development of the tradition according to which angels are created to worship Adam, who functions as the statue of God. ${ }^{68}$ The tradition achieves full development in post-Second Temple sources, but it is already witnessed in 4Q381 1,10-11:

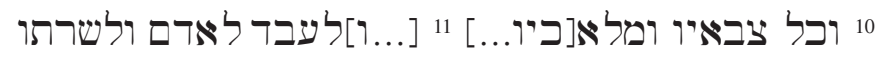

${ }^{66}$ Collins, 4QPrayer of Nabonidus... 90.

${ }^{67}$ Coxon, Another Look...; Henze, Madness... 90-99; G. Mobley, The Wild Man in the Bible and the Ancient Near East // JBL 116 (1997) 217-233, here 227-228.

${ }^{68}$ On this tradition, see G. Anderson, The Exaltation of Adam and the Fall of Satan // Literature on Adam and Eve / Ed. G. ANDERson et al. (Leiden-BostonKöln, 2000) (SVTP) 83-110; P. SCHÄFER, Rivalität zwischen Engeln und Menschen. Untersuchungen zur Rabbinichen Engelvorstellung (Berlin, 1975); J. P. Schultz, Angelic Opposition to the Ascension of Moses and the Revelation of the Law // JQR 61 (1970/1971) 282-307; A. Marmorstein, Controversies Between the Angels and the Creator // Melilah 3-4 (1950) 93-102 (in Hebrew). 
${ }^{10}$ all his hosts and [his] ange[ls... ${ }^{11}[\ldots]$ to serve man (or Adam) and to minister to him $[\ldots]^{69}$

The calligraphy belongs to the first half of the first century B.C.E., ${ }^{70}$ but multiple stylistic, ideological, and linguistic considerations determined the editor of the text, Eileen M. Schuller, to conclude that the Qumranic manuscript is itself a copy of an autograph from the Persian or early Hellenistic periods. ${ }^{71}$

Fletcher-Louis notes that the text bears witness «to a widespread belief that when Adam was originally created the angels were made to serve and even worship Adam». ${ }^{72}$ He further notes that «both the verbs and nouns which are used in 4Q381 have a strongly cultic orientation for the community that used the text». ${ }^{73}$ The expression עִ עבד ל closely parallels the common biblical phrase עבד אלדים, which refers to idol worship. ${ }^{74}$ Moreover, in the Hebrew Bible5רושר is almost exclusively used in reference to the worship of YHWH in the Temple. In Ezek 20:32 the verb refers to idol worship: שרת

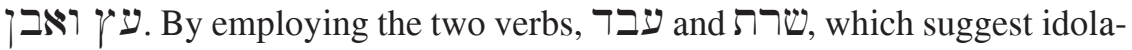
try, the text suggests that the reverence due to Adam is liturgical/iconic in nature.

The tradition underlies the reference of Daniel 3 to the serving and wor-

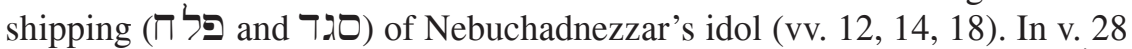
פל $\Pi$ Nebuchadnezzar decrees that the only god to be served and worshipped and (ס) throughout his empire is to be the god of Shadrach, Meshach, and Abednego. In the narrative preceding this decree, namely in Dan 2:46, Nebuchadnezzar falls prostrate and worships (סגד) Daniel. The purely liturgical connotation of the king's actions is further evinced by his order that sacrifices and incense be offered to Daniel (2:46). Both פל כגד appear in Targum Neofiti in reference to idol worship (e.g., Gen 34:31; Exod 20:5; 23:24; Num 25:5; Deut 3:29; 4:19; 5:9; 6:4; 11:6; 12:30; 26:10).

${ }^{69}$ The Hebrew text can be found in E. M. Schuller, Non-Canonical Psalms from Qumran: A Pseudepigraphic Collection (Atlanta, 1986) (HSS, 28) 71; The Dead Sea Scrolls Study Edition / Ed. F. García Martínez, E. J. C. TigchelaAr. 2 vols (LeidenNew York-Köln, 1997) Vol. 2. 754-755. The English translation is from Schuller, Non-Canonical Psalms from Qumran... 76. Schuller's text and translation are reprinted in E. M. Schuller, 4QNon-Canonical Psalms // Qumran Cave 4.VI: Poetical and Liturgical Texts. Part 1 / Ed. E. Eshel et al. (Oxford, 1997) (DJD, XI) 75-172.

${ }^{70}$ Schuller, 4QNon-Canonical Psalms... 88.

${ }^{71}$ SchulLer, Non-Canonical Psalms from Qumran... 21-52.

${ }^{72}$ Fletcher-Louis, All the Glory of Adam... 98.

${ }^{73}$ Ibid. 99-100.

${ }^{74}$ Exod 23:24, 33; Deut 4:28; 7:4, 16; 8:19; 11:16; 12:30; 13:2, 6, 13; 28:14, 36, 64; 29:18; 30:17; 31:20; Josh 23:7, 16; 24:16, 20; 1 Sam 16:19; 1 Kgs 9:6; 2 Kgs 17:35; Jer 5:19; 11:10; 13:10; 16:13; 25:6; 35:15; 44:3; 2 Chr 7:19. 
Within the parameters of this ideological context and of the tree parable, by losing his theomorphism and becoming theriomorphic, Nebuchadnezzar ceases to be object of worship and becomes worshipper. Moreover, in his angelization he also destroys the only legitimate object of iconic worship: himself. The connection with Daniel 3 and Daniel 5 suggests that the Babylonian king is only left to worship idols. The iconic-anthropologic function of the parable converges with the tradition in 4Q242, in which Nabonidus' sin-disease is depicted as idolatry.

\section{Conclusions}

Several conclusions can be safely drawn at the present stage of the research. First, Daniel 4 shares with Ezekiel 31 the imagery of an enormous tree. Several common features of the trees emerge: they are both enormous, both reach the heavens with their tops, and both have conspicuous and prominent locations. The imagery is most probably an appropriation of the Mesopotamian concept of the $m \bar{e} s u$-tree, tree that exhibits the same characteristics: it is enormous, it feeds on abundant underground waters, its top reaches the clouds of heaven, and it has a conspicuous and prominent location among the other trees.

Second, the messu-tree is the iconic tree par excellence; it provides the flesh of the gods, the material of their statues. The contexts of both Daniel 4 and Ezekiel 31 suggest that in both texts the enormous trees fulfill a similar iconic function, namely constitute iconic presences of the divine.

Third, the image of the iconic tree occurs in both Daniel 4 and Ezekiel 31 in contexts of concerns with legitimate channels of iconic worship. Like Ezekiel 28-32, Daniel 2-5 constructs a complex anthropology that identifies humanity as the only legitimate alternative to idols. Cumulative evidence leads to the tentative conclusion that already in the exilic period (Ezekiel 28 and 31) an anthropology that defined primeval humanity as the cultic statue of YHWH emerged in circles of the priestly class. The story of Daniel 4 attests to the fact that the Persian period witnessed a development of these speculations about the iconic value of humanity.

\footnotetext{
ABSTRACT

The present article offers an analysis of Daniel 4. It argues that the literary origins of the tree imagery in the biblical text most probably lie in Mesopotamian conceptions of the $m \bar{e} s u$-tree, the tree that supplies the flesh of the gods, the material of their statuary presence. The presence of the imagery in Ezekiel 31 suggests that the Mesopotamian concept was incorporated into exilic and post-exilic redefinitions of the legitimate channels of the iconic worship of YHWH. Within a priestly redefinition of YHWH's iconic presence in Judah, Adam's physical re-
} 
semblance to YHWH provided in humanity the only legitimate alternative to idol worship. Daniel 4 and its context exhibit similar ideological concerns and construct a similar solution to the ongoing iconic dilemma: humanity functions as the only legitimate equivalent of ancient Near Eastern cultic statues, as the replacement of YHWH's cultic statue of the First Temple no longer extant. The iconic connotation of the tree imagery requires a reassessment of the animal deformation of the tree, albeit a late addition to the original stratum of the narrative. Commonly interpreted through the lens of ancient Near Eastern depictions of human heroes with animal traits or life-habits, Nebuchadnezzar's loss of his dendromorphism can only mean in the terms of the parable the deformation of a theomorphic state. Within the parameters of this ideological context and of the tree parable, by losing his theomorphism and becoming theriomorphic, Nebuchadnezzar ceases to be object of worship and becomes worshipper. Moreover, in his deformation he also destroys the only legitimate object of iconic worship: himself. The context of Daniel 4, namely Daniel 3 and Daniel 5, suggests that in its deformed state humanity is only left to mistakenly worship idols. 